Revista Signos

2008, 41(67)

127-129

\section{Discurso de recepción al Doctor Giovanni Parodi Sweis como Miembro Correspondiente por Valparaíso de la Academia Chilena de la Lengua}

Valparaíso, 18 de abril, 2008

\author{
Alfredo Matus \\ Director \\ Academia Chilena de la Lengua \\ Chile
}

Con profundo regocijo, la Academia Chilena de la Lengua sesiona, una vez más, en esta espléndida ciudad de Valparaíso. Una vez más y, esperamos, no la última, sino, por el contrario, la primera de una nueva etapa, en que los destacados miembros, de número y correspondientes, de esta Universidad y de esta región, se constituyan en poderoso núcleo de proyección nacional en las delicadas tareas del cultivo planificado de nuestra lengua. Las personas están, las excelencias están, la voluntad está.

La Pontificia Universidad Católica de Valparaíso ha constituido, en la historia cultural y científica de nuestro país, un significativo y ejemplar polo de rigor y elevación, erigiéndose en un referente fundamental de la educación superior chilena. El desarrollo de sus estudios lingüísticos y literarios, por ejemplo, ha estado marcado por su nivel prominente, haciendo aportes insustituibles en los diversos ámbitos de las ciencias del lenguaje y de la literatura. Por eso, la Academia Chilena de la Lengua no puede prescindir del concurso de los hombres de letras de esta Universidad y de esta urbe, más bien los necesita imperiosamente, precisa su experiencia, su sabiduría, su consejo. Así acaeció en el pasado y así tendrá que suceder, de un modo cada vez más intenso y protagónico, en el futuro. Y, para ello, siempre ha contado con la aquiescencia del Rector de esta casa, nuestro apreciado amigo D. Alfonso Muga. Más que aquiescencia, diría yo, el apoyo decidido, incluso la instigación, el estímulo -y cuánta hospitalidad- de ese Rector, aliado, han hecho fluido este feliz contubernio. Me place recordar, a manera de justo homenaje y reconocimiento, como en otras ocasiones, la sólida figura intelectual de Luis Gómez Macker, a quien tanto deben nuestras humanidades. Y, en la hora actual, a los distinguidos hombres de letras, los académicos porteños Félix Morales Pettorino, Eduardo Godoy, Hugo Rolando Cortés, Ennio Moltedo, Marco Antonio Pinto, colaboradores leales y comprometidos con la lengua y sus valores, así como a los miembros de número, Marianne Peronard, Pa- 
tricia Tejeda y Juana Marinkovich, involucrados fervientemente en las labores habituales de nuestra Corporación, en su sede santiaguina.

Hoy tenemos la alegría de recibir, en el seno de la Academia Chilena de la Lengua, a Giovanni Parodi Sweis, científico de primera línea, de vasto prestigio nacional e internacional, Profesor de Inglés, Magíster en Lingüística Aplicada, Doctor en Lingüística por esta Universidad. Uno de los más destacados representantes de la Escuela Lingüística de Valparaíso, Premio Dr. Rodolofo Oroz 2000 de la Academia Chilena de la Lengua, editor de la prestigiosa Revista Signos, lingüista de alta trayectoria que, a través de la docencia y la investigación, ha desarrollado áreas "de punta" de la lingüística actual, como el análisis del discurso, la lingüística de corpus, la metacognición, la lingüística aplicada, la comprensión y la producción de textos escritos. No puedo disimular la emoción y la satisfacción que me embargan al tener la oportunidad de recibir a este académico y hombre excepcional.

Pero más que todo lo dicho, Giovanni Parodi Sweis es hombre de letras, un humanista a carta cabal. Un ministro de la palabra, la lectura y el libro, vale decir, del tiempo. Y estas son cosas mayores. Cuestión de hermenéutica, de sentido, esto es, de cultura, de historia, finalmente, de esa cosa tan seria que se llama justamente tiempo. Operación central de la semiótica lingüística que explica el carácter de reconstrucción y de hipótesis que encierra el quehacer explicativo de todo el fenómeno humano que en él encuentra su culminación. Pero, "soy hombre, duro poco y es enorme la noche..." y "no hay tiempo que perder...", como escribía Vicente Huidobro. Se nos impone el tiempo, esa categoría inconmensurable que nos constituye. Y no podemos esquivar la enorme, la auténtica, tal vez la única legítima interrogante. Así lo planteaba el maestro de las meditaciones, José Ortega y Gasset, al iniciar una de sus conferencias, y que yo también me formulo, con temblor, antes ustedes, apreciados amigos porteños:

"Mi pregunta es ésta, señoras y señores: ¿por qué cada uno de ustedes está ahora ahí? La cosa es más grave de lo que al pronto parece. Pues acontece que no están ahí porque han sido mecánicamente proyectados a este lugar como la bala que un cañón dispara, ni como el astro que en cada instante tiene inexorablemente que ocupar un punto de su órbita. No; cada uno de ustedes está ahora ahí porque ha venido, es decir, porque se ha traído a sí mismo en virtud de una libre resolución decidida hace algunas semanas o hace unos minutos la resolución de ocupar, esto es, de llenar esta hora de su vida en esta exclusiva y problemática forma: oír la conferencia de un pequeño señor español que tiene cara de torero. /.../ Ahora bien: esto es lo que resulta más grave de lo que parece. Porque las horas de su vida están contadas. Son muy pocas y cada una insustituible, de suerte que si gastar de ese modo esa hora resultase injustificado, algo con poco o ningún sentido dentro de la trayectoria de su existencia, equivaldría a que ha estrangulado usted ese pedazo insustituible de su vida, que lo ha asesinado, que ha cometido una fracción de suicidio". 
El sagrado ministerio de la palabra, el libro y la lectura, que ejerce, con vocación, competencia y brillo, Giovanni Parodi, se concentra en las cosas esenciales, porque no hay tiempo que perder: no puede distraerse en cosas de poca monta, porque su sustancia, su qué, su íntimo quid no es nada menos que ese supremo ejercicio humano de lo hermenéutico, del desciframiento y la interpretación, de la reconstrucción semántica, que no es más que la recomposición y reinvención del mundo y la retención del tiempo huidizo. Operación final de nuestro ser semiótico. En fin, de la denodada búsqueda del sentido en que todos andamos. Borges decía que él no obligaba a nadie a leer nada, porque no se puede obligar a ser feliz. Los académicos, en el más noble y helénico sentido, los de la Academia con mayúsculas, la del jardín de Atenas, los de la Universidad con mayúsculas, como esta, y, por cierto, también los de la Lengua, ministros todos de las letras, no obligan a nadie a ser feliz pero solo les cabe, modestamente, el grave, el noble imperativo de entusiasmar, promover, invitar... encauzar la distribución equitativa de la felicidad, a través de la palabra, el libro y la lectura. Momento supremo de la circulación cultural, y del tiempo que dura. Momento que abre los espacios de la mente al sentido, la imaginación y la locura. Tal vez, ese libro eminente, el Quijote, no sea más que el gran signo del acto de leer, de repercusiones incalculables. "En resolución -escribe Cervantes-, él se enfrascó tanto en su lectura, que se le pasaban las noches leyendo de claro en claro, y los días de turbio en turbio; y así, del poco dormir y del mucho leer, se le secó el celebro de manera que vino a perder el juicio".

En este día, en que recibimos a Giovanni Parodi Sweis, lingüista, ministro de la palabra, el libro y la lectura, no puedo más que sumarme, con entusiasmo, a celebrar este sagrado ministerio del humanista que, con tanta abnegación, quijotesca tenacidad y abierta esperanza, contribuye a afianzar los valores eminentes de lo humano: la imaginación, la locura y el sentido. 